\title{
VALOVÉ OPEVNENIE V POHORÍ BURDA NA SLOVENSKU
}

\author{
NOÉMI BELJAK PAŽINOVÁ
}

\begin{abstract}
Abstrakt: Príspevok sa sústredi na dosial’ nepublikované archeologické nálezisko v pohori Burda vokolí mesta Štúrovo v juhovýchodnom cípe juhozápadného Slovenska. V rámci záchranného výskumu Katedry archeológie Univerzity Konštantína Filozofa v Nitre v roku 2013 tu bolo zdokumentované valové opevnenie tiahnuce sa naprieč pohorím v dížke $1 \mathrm{~km}$. Skúmaný bol jeden kompletný profil v mieste jeho križovania s lesnou cestou. Príspevok si kladie za ciel' analýzu nálezového celku a pokúša sa aj o historickú interpretáciu skúmaného prameňa.
\end{abstract}

Kl'účové slová: Slovensko - pohorie Burda - valové opevnenie - pramene - historická interpretácia.

\section{A fortified wall line in the Burda Mountains, Slovakia}

Abstract: This contribution focuses on an unpublished archaeological site in the Burda Mountains, near the town of Śturovo in the south-eastern tip of south-western Slovakia. Rescue research conducted in 2013 by the Department of Archaeology of Constantine the Philosopher University in Nitra documented a onekilometre long fortified wall line running across the mountains. One complete profile in the place of its intersection with a forest track was investigated. The article analyses the find and presents the historical interpretation of the researched source.

Key words: Slovakia - Burda Mountains - fortified wall line - sources - historical interpretation.

Pohorie Burda (starší názov Kováčovské kopce; mad’. Helembai-Hegység) sa nachádza v juhovýchodnej časti územia juhozápadného Slovenska na hraniciach s Mad’arskou republikou, medzi ústím Ipla a Hrona do Dunaja (obr. 1: hore). Ide o dobre preskúmané pohorie z pohladu výskytu vzácnych biocenóz, chránených a ohrozených teplomilných druhov, ako aj z hladiska geologickej stavby, tektoniky, geomorfologického vývoja a fyzickogeografických pomerov územia (Vaškových et al. 1982).

Prírodné pomery pohoria výrazne hlavne v posledných storočiach ovplyvnil človek, tak priamymi zásahmi do pôvodných lesných fytocenóz, ako aj tvorbou nových antropogénnych foriem a biotopov (t. j. kameňolomy po t’ažbe najmä brekcií a konglomerátov), či urýchl’ovaním geomorfologických procesov (napr. výmol’ovej erózie).

Z morfologického hl'adiska je pohorie Burda hrast'ovou neotektonickou štruktúrou (odrezanou kryhou), vyzdvihnutou pozdĺž zlomových porúch o 250-300 m. Pohorie dosahuje najvyššiu výšku v centrálnej časti. Najvyšším vrchom územia nie je eponymný Burdov (388 m), ale bezmenná kóta juhozápadne od neho, ktorá je ešte o sedem metrov vyššia. Priemerná nadmorská výška pohoria je 237,19 m (Pišút-Procházka-Bandura 2016, 7). Prirodzenou hranicou pohoria z južnej strany je antecedentná dolina Dunaja, na východnej a severovýchodnej strane je to riečna dolina pri ústí Ipl'a, založená taktiež na zlome. Na severozápade Burdu od Ipel'skej pahorkatiny oddel'uje Bajtavské sedlo, ktorým prechádza štátna cesta II. triedy z Kamenice nad Hronom do Salky (Pišút-Procházka-Bandura 2016, 6-7).

Archeologické náleziská sú bohato zastúpené v širšej oblasti pohoria v priestore sútoku riek Hron, Ipel' a Dunaja v juhovýchodnom cípe Podunajskej pahorkatiny. Táto oblast' patrí na území Slovenska k najhustejšie osídlením územiam, počínajúc pravekom a končiac novovekom (Beljak Pažinová-Šaliová 2017).

Prvýkrát sa val v pohorí Burda spomína v publikáciách z prelomu 19. a 20. storočia. Uvádza sa, že sa nachádza medzi obcami Chl'aba a Lel’a, vybudovaný bol zo spečenej hliny a považovaný bol za obrannú stavbu Kvádov proti nepriatel'om z východu (Borovszky 1906, 281). Mal nadväzovat' na d'alšie valové systémy, ktoré viedli s niekol'kými prerušeniami až na Sitno. Val v pohorí Burda však nikdy nebol skúmaný, resp. archeologicky zdokumentovaný.

V rámci záchranného archeologického výskumu realizovaného Katedrou archeológie FF UKF v Nitre v roku 2013 počas rozširovania lesnej cesty „Dona potok“, prechádzajúcej pohorím 


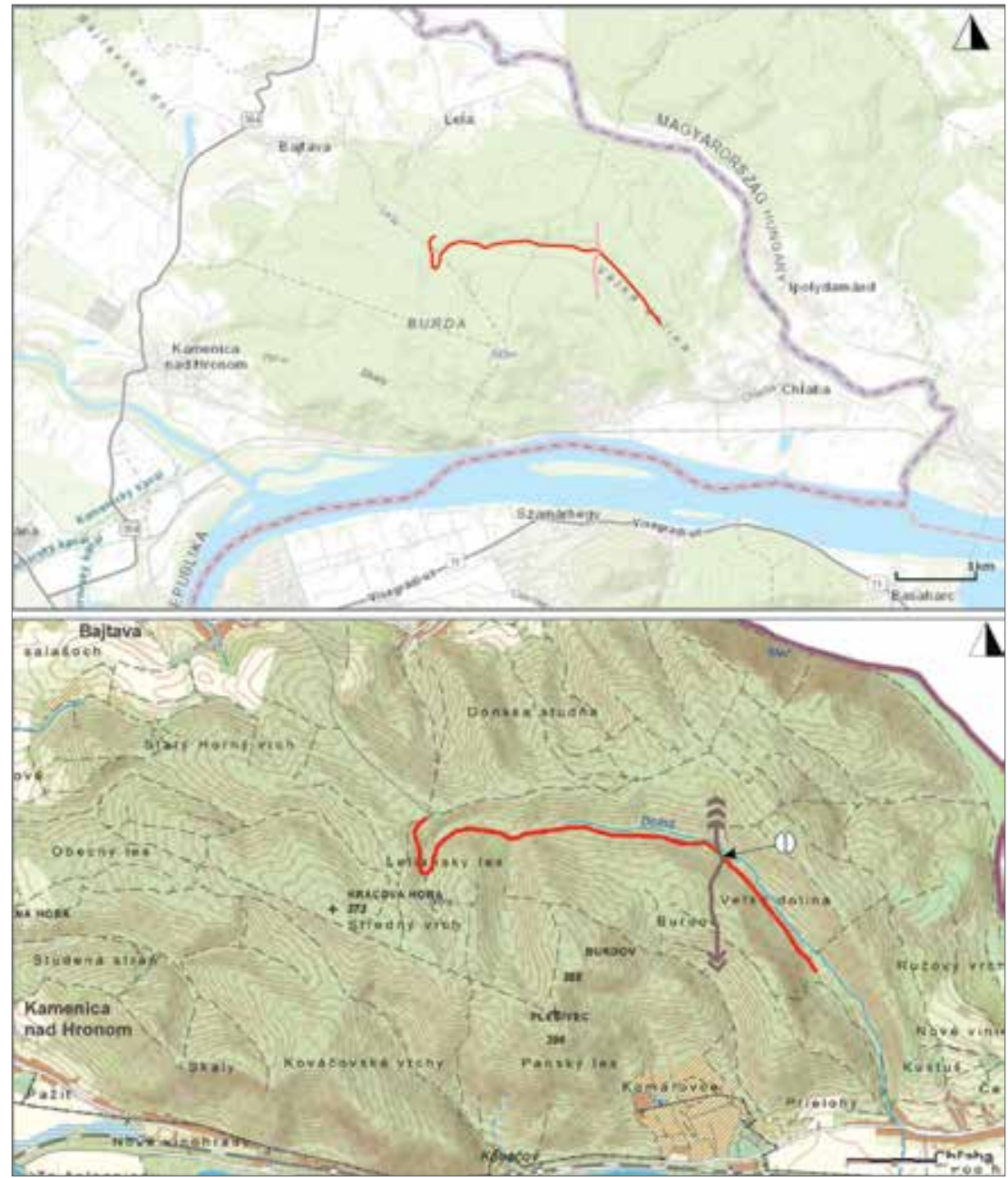

Obr. 1. Situovanie pohoria Burda v juhovýchodnom cípe Podunajskej pahorkatiny na hraniciach s Mad'arskou republikou (A) a detail na pohorie Burda a lesnú cestu Dona potok, vyznačenú červenou farbou, a zemný val naznačený hnedou líniou. 1 - zdokumentovaný južný profil valu v mieste križovania s lesnou cestou. Autor N. Beljak Pažinová.

Abb. 1. Lage des Burda-Gebirges im südöstlichen Zipfel des Donauhügellandes an der Grenze zur Republik Ungarn (A) und Detail des Burda-Gebirges mit rot gekennzeichnetem Waldweg Dona potok und mit brauner Linie markiertem Erdwall. 1 - dokumentiertes Südprofil des Walles an der Stelle, an der er den Waldweg kreuzt. Erstellt von N. Beljak Pažinová.

Burda od obce Bajtava do Chl’aby, sa toto rozsiahle valové zemné opevnenie tiahnuce sa naprieč pohorím podarilo lokalizovat' a podl'a možností zdokumentovat'. Ciel'om príspevku je analýza preskúmanej nálezovej situácie a pokus o interpretáciu dejinných súvislostí objaveného prameňa.

\section{Zemné valové opevnenie v pohorí Burda}

Archeologický výskum realizovaný v pohorí Burda v roku 2013 bol vyvolaný stavbou „Lesná cesta Dona potok“, ktorá spočívala z rekonštrukcie existujúcej protipožiarnej lesnej 
cesty vedúcej naprieč pohorím a prechádzala katastrálnym územím troch obcí: Bajtava, Chl’aba a Lel'a. Ciel'om zemných prác bolo spevnenie existujúcej trasy lesnej cesty, resp. zosilnenie povrchu vozovky, úprava krajníc a rekonštrukcia pozdížnych a priečnych odvodnení cesty. Celková dížka rekonštrukcie komunikácie bola $3,6 \mathrm{~km}$. Cesta začínala v katastri obce Bajtava na križovatke (v sedle) Rázcestie na Bajtavu, v kilometri 2,8 sa napájala na značenú turistickú cestu (TZT 2438 modrá), po ktorej pokračovala necelý kilometer, a končila v katastri obce Chlaba, približne $1 \mathrm{~km}$ od intravilánu obce (obr. 1).

Zemné práce na rekonštrukcii cesty boli sledované od októbra 2012 do júla 2013. Počas jesenných zemných prác sa v katastri obce Chl'aba podarilo identifikovat' zemný val, ktorý bol archeologicky skúmaný na jar. Objavil sa v km 2,75 pri rozširovaní cesty zarezaním do svahov a v miestach s prudším svahom nad cestou zosvahovaním do miernejších sklonov. Val, ktorý pôvodná cesta prerezala už v minulosti, bol zdokumentovaný v reze v mieste, kde ho lesná cesta „Dona potok“ križovala (obr. 2).

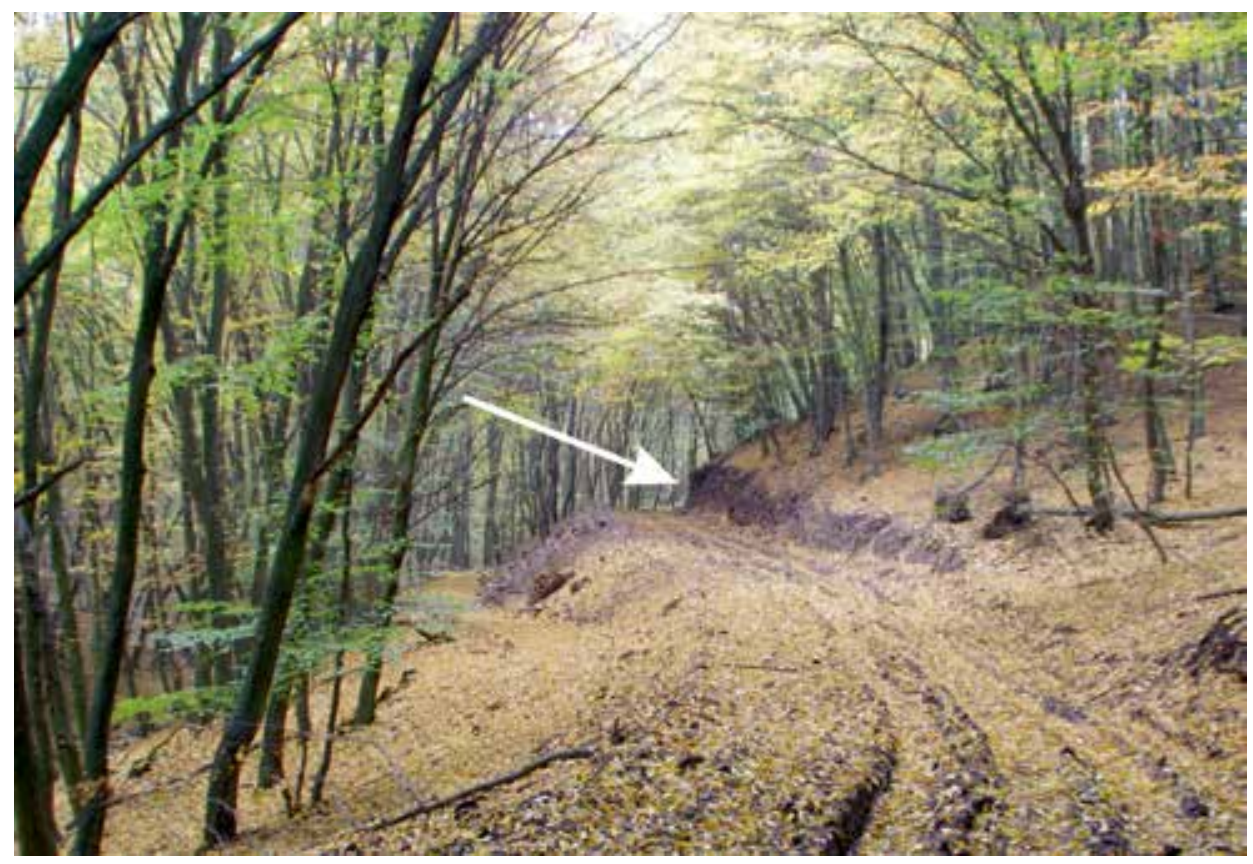

Obr. 2. Miesto križovania lesnej cesty Dona potok a zemného valu v pohorí Burda na jeseň 2012. Foto N. Beljak Pažinová. Abb. 2. Stelle, an welcher sich im Herbst 2012 der Waldweg Dona potok und der Erdwall im Burda-Gebirge kreuzten. Foto N. Beljak Pažinová.

\section{Opis valu}

Objekt valu sa našiel v km 2,75 (stredový bod: -451124,478; -1325418,523) pri rekonštrukcii a obnove lesnej cesty „Dona potok“ v pohorí Burda. Lesná cesta priečne prerezala val už v minulosti a pomerne dobre zachovaný zostal jeho južný profil, týčiaci sa nad cestou. Protil'ahlá (severná) strana valu bola v úseku približne $50 \mathrm{~m}$ zničená d’alšími lesnými cestami, pri ktorých výstavbe bolo teleso valu splanírované. Tiež už nie je z terénnej situácie jasné, ako val prekračoval lesný potok Dona, ktorý tu tečie západo-východným smerom.

Zachovaný južný profil valu bol začistený ručne na celú šírku (obr. 3). Vzhl’adom na súčasnú výšku valu $3 \mathrm{~m}$ sa profil nechal mierne sklonený pod uhlom ca 50-60 stupňov, aby sa výrazne 
nezosúval. Dížka valu pri základni dosahovala $13 \mathrm{~m}$ a maximálna výška v strede profilu bola takmer $3 \mathrm{~m}$ s postupným viac-menej rovnomerným klesaním po oboch stranách (obr. 4).

Podklad valu tvorí svetložltá sprašovitá vrstva hliny s mocnostou min. 0,3-0,4 m (SJ01), na ktorej leží 0,2-0,3 m hrubý pás kameňov (SJ02) z miestnych vulkanických zdrojov (andezity, zlepence). Tie sa smerom k okrajom valu strácajú. Nad kameňmi sa nachádzala $0,7-0,8 \mathrm{~m}$ hrubá vrstva hnedej hliny (SJ03) bez prímesí. Z východnej strany ju zhruba do dvoch tretín šírky valu prekrýva sivohnedá mazl'avá nepravidelná vrstva hliny s hrúbkou 0,4-0,7 m (SJ04). Na nej, v strednej časti valu, leží sypkejšia hnedá hlina bez prímesí až po vrch (SJ05). Na východnom svahu je na povrchu iba niekol'ko centimetrov $(0,06-0,1 \mathrm{~m})$ hrubá vrstva lesného humusu (SJ06). Podobná sivá hlina sa nachádza na povrchu západného svahu (SJ07). V najvyššom bode dosahuje skúmaný profil valu nadmorskú výšku $223,7 \mathrm{~m}$.

Vo východnej časti je val porušený koreňom stromu, v západnej časti je zhruba do 0,4$0,5 \mathrm{~m}$ híbky viditel'ná jama (pravdepodobne tiež po koreňoch stromu) s väčšími kameňmi. Na západnom upätí valu sa nachádza kol'aj po lesnej technike ako pozostatok po novovekej t’ažbe dreva. Výraznejšia priekopa prislúchajúca k valu nie je viditel'ná, avšak z východnej strany valu to konfigurácia terénu nevylučuje.

Priebeh valu sa podarilo v teréne zmerat' celkovo v dížke okolo $1 \mathrm{~km}$ (obr. 1). Val je v pohorí Burda orientovaný v smere sever-juh a smeruje od časti Burdov, kde najvyšší bod valu dosahuje výšku takmer $300 \mathrm{~m}$ n. m. (d’alej južným smerom k obci Chl'aba je viditel'ný dlhší strmý

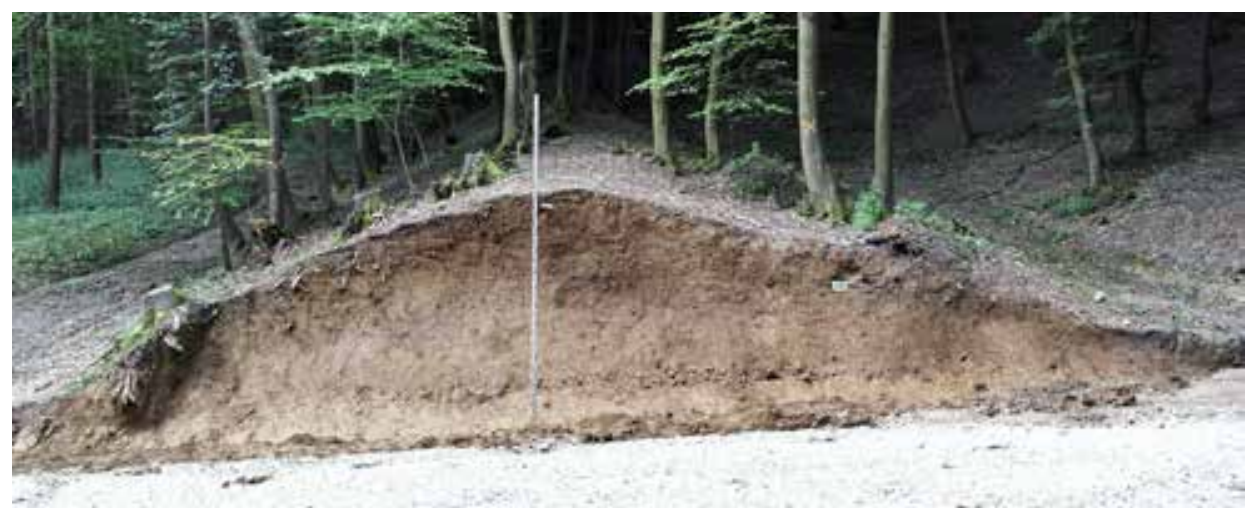

Obr. 3. Pohorie Burda, lesná cesta Dona potok. Zemný val. Fotodokumentácia južného profilu na jar 2013. Foto N. Beljak Pažinová.

Abb. 3. Burda-Gebirge, Waldweg Dona potok. Erdwall. Fotodokumentation des Südprofils im Frühjahr 2013. Foto N. Beljak Pažinová.

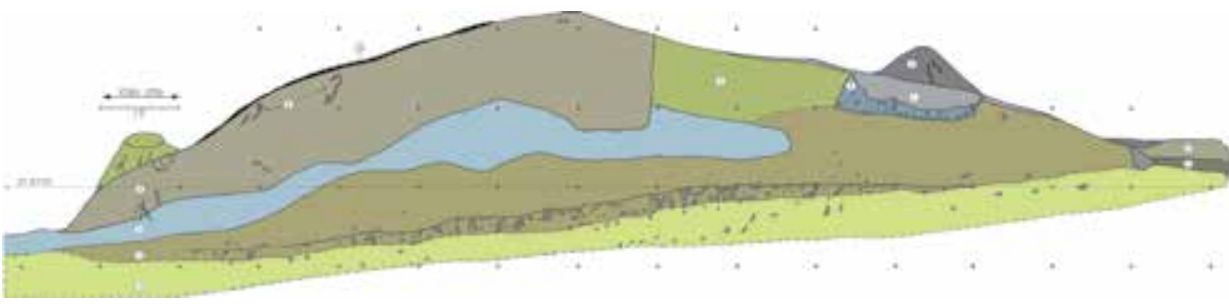

Obr. 4. Pohorie Burda, lesná cesta Dona potok. Zemný val. Kresba južného profilu. 1 -svetložltá ílová hlina; 2 -svetlohnedá vrstva; 3 - sivohnedá mazl’avá hlina; 4 - hnedá sypká hlina; 5 - hnedá sypká drobivá hlina; 6 - sivohnedá vrstva s kameňmi; 7 - sivá vrstva; 8 - tmavosivá hlina; 9 - korene; 10 - tmavá humusová vrstva; 11 - tmavohnedá hlina; 12 - svetlohnedá hlina. Autori M. Melo, M. Styk, O. Žaár, L. Žaárová, N. Beljak Pažinová.

Abb. 4. Burda-Gebirge, Waldweg Dona potok. Erdwall. Zeichnung des Südprofils. 1 - hellgelb toniger Lehm; 2 - hellbraune Schicht; 3 - graubrauner schmieriger Lehm; 4 - brauner lockerer Lehm; 5 - brauner lockerer bröckeliger Lehm; 6 - graubraune Schicht mit Steinen; 7 - graue Schicht; 8 - dunkelbrauer Lehm; 9 - Wurzeln; 10 - dunkle Humusschicht; 11 - dunkelbrauner Lehm; 12 - hellbrauner Lehm. Erstellt von M. Melo, M. Styk, O. Žaár, L. Žaárová, N. Beljak Pažinová. 
kamenistý zráz, kde výstavba valu nebola potrebná). Následne val križuje lesnú cestu „Dona potok“ (kde bol zdokumentovaný profil), ktorá tu ústí do Vel'kej doliny. Vel'ká dolina je najväčšou dolinou pohoria Burda. V dížke vyše $4 \mathrm{~km}$ rozčleňuje celú východnú polovicu pohoria a zasahuje až do jeho centra. Má charakter úvalín v spraši a sprašových hlinách, ktoré zaviali svahy pohoria v kvartéri (mladšom pleistocéne). Ústie doliny (pri Chl'abe) predstavovalo „vstupnú bránu“ expanzie človeka dovnútra pohoria (Pišút-Procházka-Bandura 2016, 7).

Severným smerom od zdokumentovaného profilu za potokom Dona, ktorý predstavuje jeden z mála stálych tokov v dolnej časti Vel'kej doliny a ústí pri Chl'abe do Dunaja, val pokračuje mierne severozápadným smerom v blízkosti pravej strany značenej modrej turistickej trasy smerujúcej ku kóte Pri troch studničkách. Val popri turistickej trase pokračuje približne $300 \mathrm{~m}$, kým sa v teréne plynule nestráca (v tejto časti dosahuje nadmorskú výšku $250 \mathrm{~m}$ ).

Hoci v súčasnosti viditel'ná línia valu zasahuje len do katastra obce Chl'aba, ktorej intravilán (prvé domy) je od valu v mieste križovania s lesnou cestou vzdialený $2 \mathrm{~km}$, podl'a severojužného smerovania valu je možné, že pôvodne siahal od časti Burdov nad obcou Chlaba až po obec Lela na severnej strane pohoria Burda.

Povrchový prieskum realizovaný na temene valu a po jeho stranách bol negatívny. Žiadne d’alšie nálezy sa nenašli ani počas obhliadok ostatnej trasy rekonštruovanej lesnej cesty Dona potok.

\section{Datovanie a interpretácia valového opevnenia}

Na zdokumentovanom vale v pohorí Burda, $v$ jeho blízkosti ani v telese valu sa počas prieskumov a výskumu nenašli žiadne hnutel'né archeologické nálezy, ktoré by pomohli k jeho presnejšiemu datovaniu, resp. naznačili jeho funkciu. Je preto potrebné upriamit' pozornost' na analogické archeologické objekty i historické pramene v bližšom aj širšom okolí.

Zemné valové systémy nie sú na území dolného Pohronia a Poiplia žiadnou raritou. Medzi prvými dlhé valové systémy v Honte analyzovali F. Rómer (1876) i I. Henszlmann (1878, 248, 249). V oblasti Štiavnických vrchov a Krupinskej planiny sa o fenomén tzv. „spečených valov“ zaujímal už koncom 19. storočia A. Kmet’ (Medvecký 1924, 145-152). Viaceré publikoval a geodeticky zameral Š. Janšák (1938).

Zastaraný názov „spečený val“" sa na Slovensku, resp. v Mad’arsku (,,vörössánc“) pre tieto valové systémy použival z toho dôvodu, že mnohé nesú výrazné stopy prepálenia. Pri názve sa pôvodne vychádzalo z predstavy o zámernom spevňovaní týchto opevnení spálením drevenej výplne, pričom sa hlina a kamene prepálili, miestami až spiekli do keramickej až sklovitej trosky. Spečenie valu ako stavebná technika však nie je v odbornej spisbe dlhodobo uznávaná, skôr sa tento úkaz pripisuje záverečnej etape existencie určitej fázy valového opevnenia, po ktorom mohol byt' obnovený, alebo definitívne opustený (napr. Nováki-Sándorfi 1987; Štefanovičová 1987).

Sústava dlhých valov sa tiahne od Štiavnických vrchov po západnom brehu Hrona až k Dunaju a predhorím Štiavnických vrchov až k Ipl'u. Trasy línií dlhých zemných valov sa však dajú rekonštruovat' iba čiastočne (Beljak 2010, 359-362). Väčšina zachovaných úsekov (situovaných hlavne v lesoch na predhoriach Štiavnických vrchov) má formu kamenného násypu širokého 4-6 $\mathrm{m}$ a vysokého $1-2,5 \mathrm{~m}$. Čast' kameňov je roztavených a roztečených do sklovitej hmoty, čo je neklamným dôkazom, že val bol vystavený mimoriadne vysokej teplote. Na poliach sa postupným oraním zničil do takej miery, že je čitatel'ný iba v podobe dočervena prepálenej hliny. Valová línia je dnes bezpečne doložená v katastrálnych územiach hontianskych obcí Pečenice (okr. Levice), Bátovce (okr. Levice), Žemberovce (okr. Levice), Súdovce (okr. Krupina), Hontianske Moravce (okr. Krupina) a Dolné Semerovce (okr. Levice). Spomína sa aj v Jabloňovciach (okr. Levice).

Archeologicky skúmaný bol zemný val v Ipel'skej pahorkatine pri obci Žemberovce v polohe Čriepeš, kde ho v rokoch 1976-1977 prebádal T. Kolník (1978). Potvrdil komorovú konštrukciu drevozemného valu a hrotité priekopy po oboch stranách, ktoré sú od seba vzdialené $17 \mathrm{~m}$. Celková výška valu mohla dosahovat' 5-6 m. Ďalší výskum uskutočnili T. Kolník a P. Roth 
(1984, 119-122) na západnom brehu Hrona v Novom Tekove. Val sa v priestore Slovenskej brány tiahne pozdĺž dnešnej cesty do Kozároviec a Hronského Beňadika. Základňa valu mala šírku $16-17 \mathrm{~m}$ a val dosahoval ešte výšku 2,1-2,6 m. V tomto prípade bola identifikovaná priekopa lemujúca val len z východnej strany. Výplň valu tvoril výlučne íl a jadro pozostávalo z drevenej konštrukcie, ktorá bola spevnená zeminou a kamením. Zároveň sa tu zistilo, že z vonkajšej (východnej) strany bola palisáda zdvojená (spevnená), zrejme bola prestavaná či opravovaná. Väčšie množstvo prepálenej hliny a zvyšky zuhol'natenej drevenej konštrukcie, objavené pri výskume, boli spájané so zánikom valu pri nejakej katastrofe.

Interpretácia výstavby týchto valových systémov dodnes nie je vyriešená. Otázne je kedy, kto a proti komu ich postavili. T. Kolník $(1978,139)$ ich spája s komplikovanou politickou situáciou na strednom Dunaji v 4. stor. po Kr. a domnieva sa, že tieto fortifikácie mali plnit’ úlohu ochrannej bariéry proti kočovníkom z východu. Podla tejto hypotézy bolo vybudovanie valov výsledkom spolupráce Rimanov so Sarmatmi a Kvádmi (Kolník 1999, 163-176). Túto skutočnost' však neguje výsledok analýzy organického materiálu z telesa valu v Žemberovciach v polohe Čriepeš, ktorá priniesla datovanie 1190 +/- BP, čiže okolo roku 760 po Kr. (Kolník 1978, 140-141).

Je pravdepodobné, že rozsiahle pevnostné systémy známe z územia Slovenska nadväzovali na podobné valové opevnenia z územia dnešného Mad’arska, Rumunska a Srbska. V Potisí sú známe ako tzv. sarmatské valy. Vybudovali ich pravdepodobne v neskorej dobe rímskej v 4. storočí po Kr. (Soproni 1978, 128-130; Visy 1988, tab. 10). S. Soproni $(1969,48)$ kladie výstavbu jeho najjužnejšej a najsevernejšej časti do obdobia po roku 322 po Kr. a výstavbu prostredného priebehu valov do doby po roku 358 po Kr. Kl'účovou lokalitou pre interpretáciu tejto zložitej stavby je neskorosarmatské pohrebisko Mezőszemere-Kismari fenék (Vaday 2001, 249-276; Istvánovits-Kulcsár 2002, 625-627). Sú na ňom pochovaní Sarmati, ktorí v 4. storočí po Kr. bránili v kooperácii s Rimanmi líniu týchto valov pred nomádskymi kmeňmi, útočiacimi na Panóniu z východu. Val a pohrebisko sú v superpozícii, teda niektoré hroby sa nachádzali aj pod základňou valu, ktorý musel byt’ postavený neskôr, ako boli jedinci pochovaní.

Dôkazy o budovaní dlhých zemných valov máme aj zo včasného stredoveku. Napríklad ned'aleko Pustého hradu vo Zvolene sme v roku 2010 skúmali val s drevozemnou komorovou konštrukciou a priekopou (Beljak-Pažinová 2012, 298-305). Val sa tiahol v dížke 509 m v smere severozápad-juhovýchod až po cestu nad Neresnicou a vykazoval $84 \mathrm{~m}$ prevýšenie (od 380 po $454 \mathrm{~m}$ n. m.). V mieste výskumu val dosahoval výšku $1,3 \mathrm{~m}$ a šírku $9 \mathrm{~m}$. Priekopa široká $5 \mathrm{~m}$ a hlboká min. 1,2 m lemovala val z juhu a bola vytesaná do skalného podložia. Vnútro drevenej dubovej komory bolo široké $3 \mathrm{~m}$ a našli sa tu prepálené zvyšky po dubových trámoch hrubých približne $0,7 \mathrm{~m}$. Drevená komora bola vyplnená miestnym žltým lesným ílom. Pôvodnú výšku valu môžeme na základe výpočtu hmoty pochádzajúcej z jeho komôr a nachádzajúcej sa v jeho bezprostrednej blízkosti odhadnút' na minimálne $4 \mathrm{~m}$. Obranu znásobovala priekopa. Útočníci tak mali pred sebou t’ažko priechodnú bariéru z juhu do Zvolenskej kotliny. Val na lokalite Zvolen, poloha Drahy, bol rádiometrickou metódou datovaný do 7.-8. storočia (1280 +/- 40 BP; $92,5 \%$ pravdepodobnost' datovania medzi roky $650-830$ po Kr.). Datovanie vzorky je analogické vzorke z dubovej komory valu zo Žemberoviec - Čriepeša (okolo 760 po Kr.).

Doklady líniových obranných stavieb zo záveru včasného stredoveku sú známe aj v Zadunajsku (Kiss-Tóth 1987, 113, 130, 13. kép). Dôležité je v tomto kontexte spomenút' 8 km dlhé zemné šiance s komorou konštrukciou (šírka komory 2-3 m) a s priekopou (šírka 6-7 m, híbka 2-2,5 m), zo západnej strany tiahnuce sa južne od mesta Vasvár až po Győrvár vo Vašskej (Železnej) župe (Kiss-Tóth 1987, 113, 126). Zemný val bol v celom úseku prerušený len na jednom mieste 3-4 m širokou bránou, zvanou „Vaskapu“ (Železná brána). Cez bránu viedla jediná cesta, ktorá na kartografických i v písomných prameňoch bola uvádzaná ako „Katonák útja“ (cesta vojakov) a bola stotožňovaná so starou obchodnou a vojenskou rímskou cestou. Dlho sa preto verilo, že val bol postavený už v dobe rímskej (Járdányi-Paulovits 1949, 1-5; Nováki 1964). Výskum v roku 1985 (Kiss-Tóth 1987, 113, 126) však uviedol na správnu mieru čas výstavby opevnenia do záveru včasného stredoveku, konkrétne do druhej polovice 10. storočia, s funkciou obrany včasných hraníc Uhorského královstva zo západu, resp. juhozápadu. Cesta, ktorá val 
križovala, bola zároveň identifikovaná ako dial'ková cesta vedúca z Talianska „via Latinorum“ (1274), resp. zo Slovínska „via magna Murauta“ (1326; Kiss-Tóth 1987, 107-108). Výskum valu taktiež objasnil spôsob výstavby tohto opevnenia. Identifikované boli dve stavebné fázy. V prvej etape bolo postavené teleso valu (šírka $6 \mathrm{~m}$ a výška $2 \mathrm{~m}$ ) z hlinenej výplne híbenia priekopy. Na tomto vale stála od strany priekopy približne 2,5 m široká drevená komorová konštrukcia, ktorej hlinená výplň po určitom čase prešla žiarom a bola prepálená až do červena. Po zhnití a vypálení drevenej konštrukcie bolo teleso valu opätovne navŕšené a rozšírené žltou hlinou. Tieto skutočnosti svedčia teda o dlhom užívaní objektu (Kiss-Tóth 2001). Analogickú techniku výstavby vykazujú valy s komorovou konštrukciou a spálenou výplňou napr. aj na hradoch v Novohrade: hrad Hont (Mordovin 2013, 13-19), hrad Bernecebaráti (Nováki-Sándorfi-Miklós 1979, 45-46), ale aj v Nitre (Bednár-Samuel 2004, 328-330; Bednár 2012, 45-46) či Bratislave (Štefanovičová 1975, 28, 46-47; 1998, 431). Ich výstavbu bádanie datuje do 10.-11. storočia, následné prestavby sa predpokladajú na konci 11. storočia a v 12. storočí.

V písomných prameňoch sa pohorie Burda prvýkrát spomína už v roku 1138, v súvislosti s darovaním tridsiatich troch chl'abianskych (Villa Helemba) rybárov Demešskému (mad'. Dömös) prepošstvu so zemou pri Ipli a s vel'kým lesom „Piscatores cum terra et magna silva et cum tana predicta in Ipuli flumine dati sunt" (Knauz 1874, 94; Borovszky 1906, 45). Súčast'ou královského revíru sa lesy Burdy stávajú v 13. storočí. Potreba ochrany lesov ako pol’ovného revíru vyvolala vznik úplne novej vrstvy strážcov královských lesov (custodem silvarum), ktorí sa v Chl'abe spomínajú už v roku 1262 (Mészáros 1997, 192). V tejto listine sa nachádza opis východnej časti Burdy medzi dnešnou Vel'kou dolinou (dolnapataka) a Ipl’om. Spomína sa zároveň aj Sedlový vrch (Nergesberch) nad Chl'abou, doliny Sarkanus a Pachawelge, ako aj Strážny vrch (Heurhegh). V tom čase už územie pretkávala siet' vnútrochotárnych a miestnych ciest (Ivanič 2011, 34, 53, Mapa 6.), spájajúca jednotlivé úpätné obce, napr. Lel’u s Damásdom „(...) ad viam (...) de Leled uersus Damas“ (Knauz 1874, 472; Pišút-Procházka-Bandura 2016, 17).

Strategický význam mohlo mat' pohorie Burda a jeho okolie v období osmanských vojen. Jeho pozícia na pomedzí ústia Hrona a Ipl'a, pozdíž ktorých viedli dôležité obchodné trasy na sever, určite nezostala bez povšimnutia. Od polovice 16. storočia (1543 dobytie Ostrihomu a parkanskej pevnosti) až do poslednej štvrtiny 17. storočia (1683 oslobodenie Štúrova) bola táto oblast' frontovým územím medzi Osmanskou ríšou a Habsburskou monarchiou. Okrem predsunutej drevozemnej palánky Džigerdelen, postavenej na území dnešného Štúrova (Hegyi 2007, 686-750), dal ostrihomský beg vybudovat' v roku 1581 aj drevozemnú palánku Damaschki (Derbend) pri východnom okraji Burdy, na pahorku nad Ipl’om (Hegyi 2007, 681-685). Ležala na severnom okraji dnešnej obce Ipolydamásd, zrejme na ruinách stredovekého loveckého zámku, ktorý pramene spomínajú ako král'ovský majetok od roku 1361 a poslednýkrát v roku 1523, ked' ju král' L'udovít II. daroval ostrihomskej kapitule. Tento hrad zanikol zrejme na začiatku tureckej nadvlády regiónu (Nováki-Sándorfi-Miklós 1979, 47; Miklós 1989; Hegyi 2007, 685). Turecká palánka Derbend mala kontrolovat’ strategicky významnú komunikáciu dolinou Ipl'a. Lokalita bola síce Turkami opustená a podpálená už v roku 1584 po úspešnom vojenskom t’ažení cisárskych vojsk, avšak po žitavskom mieri (1606) ju obnovilo a zosilnilo cisárske vojsko (1610-1620). Dokonca v roku 1622 sa tu spomína aj tridsiatková mýtna stanica (Korcsmáros 1995), ktorá bola dôležitým zdrojom príjmov Uhorskej král’ovskej komory. Turci z Vácu ju však v roku 1646 definitívne zrovnali so zemou.

Kartografické pramene prinášajú taktiež zaujímavé skutočnosti. Prvý podrobnejší nákres pohoria Burda je na mape Hontianskej stolice ${ }^{1}$ z roku 1742, ktorú zhotovil Samuel Mikovíni ako súčast' série máp stolíc Uhorska pre Notície Mateja Bela. Pohorie na mape predstavuje najjužnejšiu čast' pomerne súvislého pásu členitejšieho územia, situovaného medzi Dunajom, Hronom a Ipl'om. Z okolitých obcí sú zakreslené Kamenica (Kövesd), Lel'a (Lelert) a Chl'aba (Hellemba), chýba dedina Bajtava.

Na mape 1. vojenského mapovania (1782-1785) je vel'mi zaujímavá vyznačená odlesnená enkláva (obr. 5, vl’avo) v severovýchodnej časti pohoria s miestnym názvom Sjaniec B.[erg] (šiance, t. j. valy, násypy; z nem. Schanz; Šancový vrch). Tento názov môže poukazovat' na 
existenciu bližšie nešpecifikovanej fortifikácie vo výšinnej polohe nad dolinou Ipl'a v pohorí Burda. Podla mapy ide o odlesnenú enklávu trojuholníkovitého pôdorysu ležiacu v mieste, kde sa spájali miestne cesty vedúce pohorím Burda z Bajtavy a Lele do Chl'aby. Nakol'ko je tento priestor vyznačený ako bezlesie, mohlo íst' o oráčiny, pričom okolité svahy boli zalesnené. Na 2. vojenskom mapovaní (mapový list z roku 1842) je nad’alej vyznačená, hoci menšia, odlesnená enkláva medzi Lel’ou a Chl'abou, avšak jej názov sa vytratil (obr. 5, vpravo). Zaujímavé však je, že sa tu nachádza nový miestny názov na vyvýšenine východne od obce Lel’a. Je tu toponymum Varallya B.[erg], čo v preklade znamená vrch Podhradie, prípadne Podhradský v.[rch]. I ked'si uvedomujem nepresnosti v interpretácii zemepisných názvov, nemožno vylúčit' možnost', že nad obcou kedysi stálo opevnenie. Termín Sancz sa v odlesnenej severovýchodnej časti pohoria Burda opätovne objavuje aj na 3 . vojenskom mapovaní ${ }^{2}$ (mapový list z roku 1885). Tu sú už prvýkrát uvedené aj nadmorské výšky a v prípade miestnych názvov sa na mape prvýkrát objavuje aj pomenovanie Nagy völgy (Vel'ká dolina). Spomenút' treba aj skutočnost', že na mieste toponyma Varallya $B$., ktoré bolo na druhom vojenskom mapovaní, sa na tret’om mapovaní vyskytuje názov Várhegy (hradný vrch).

Dočasné odlesnenie, presvetlenie výšinných polôh, ako je zaznačené v polohe Šiance na vojenských mapovaniach, malo nepochybne aj obranný význam a poukazuje na strategickú polohu pohoria medzi významnými stredovekými hradmi (Ostrihom, Visegrad, Ipolydamásd hrad Damásd) a vojenskými fortifikáciami (Ipolydamásd - Damaschki, Štúrovo - Džigerdelen) v 16. a 17. storočí.

\section{Diskusia}

Ked' si porovnáme preskúmaný val v pohorí Burda a tzv. „spečené valy“ v Honte, Tekove alebo na Potisí, resp. známe stredoveké valy s komorovou konštrukciou, na prvý pohl'ad sú zrejmé konštrukčné odlišnosti. V mieste rezu valom v pohorí Burda neboli zaznamenané žiadne zvyšky po drevenej palisáde tvoriacej jadro valu, resp. prepálená zemina, prípadne zvyšky uhlíkov. Rovnako tu neboli zachytené žiadne archeologické nálezy, ktoré by pomohli bližšiemu zaradeniu objektu. Z toho dôvodu je potrebné konštatovat', že v súčasnej situácii nie je možné stanovit' čas výstavby valu, resp. jeho funkciu či účel. Dovolím si však tvrdit', že ide o antropogénny relikt a na základe jeho situovania tvoril zátarasu cesty (ciest?) smerujúcej naprieč pohorím Burda z východu (údolie Iplaa) na západ (údolie Hrona). Zatial' nemožno vylúčit' na začiatku spomínané tvrdenie S. Borovszkého (1906, 281), ktorý ako prvý val spomenul a jeho výstavbu pripísal germánskym Kvádom. Rovnako je však možné, že obrannú líniu v Burde postavili neskôr, prípadne mohol byt' využívaný aj dlhšie časové obdobie, resp. slúžil vo viacerých dejinných obdobiach. To však bude možné zistit' až d’alšími terénnymi výskumami.

\section{Zhrnutie}

V príspevku bola predstavená doposial' neskúmaná archeologická lokalita objavená v rámci záchranného výskumu Katedry archeológie FF UKF v Nitre v roku 2013. Pri rozširovaní lesnej cesty Dona potok v pohorí Burda, nachádzajúcom sa v juhovýchodnom cípe územia juhozápadného Slovenska, sa podarilo identifikovat' zemný val. Tiahne sa severojužným smerom naprieč pohorím medzi obcami Chl'aba a Lel’a. Čas jeho výstavby nie je známy, avšak indície poukazujú na jeho funkciu zatarasenia ciest vedúcich naprieč pohorím medzi údolím Ipla a Hrona. Hoci v analyzovaných prameňoch nie je jednoznačná zmienka o zemnom vale prechádzajúcim pohorím Burda, je jasné, že kl’účové pri jeho výstavbe boli pohnuté vojenské časy, ktoré však zatial' nevieme presne zaradit'. Vylúčit' nemožno ani opakované využitie objektu v rozličných obdobiach. Zaujímavú indíciu o existencii opevnenia v pohorí Burda ponúkajú historické vojenské mapovania z 18. storočia, kde sa v blízkosti miesta zistenia valu v severovýchodnej časti pohoria opätovne objavuje odlesnená enkláva a pomenovanie „šiance“.

2 Vol'ne dostupné na: https://mapire.eu/hu/map/thirdsurvey75000/, cit. 28. 11. 2018. 

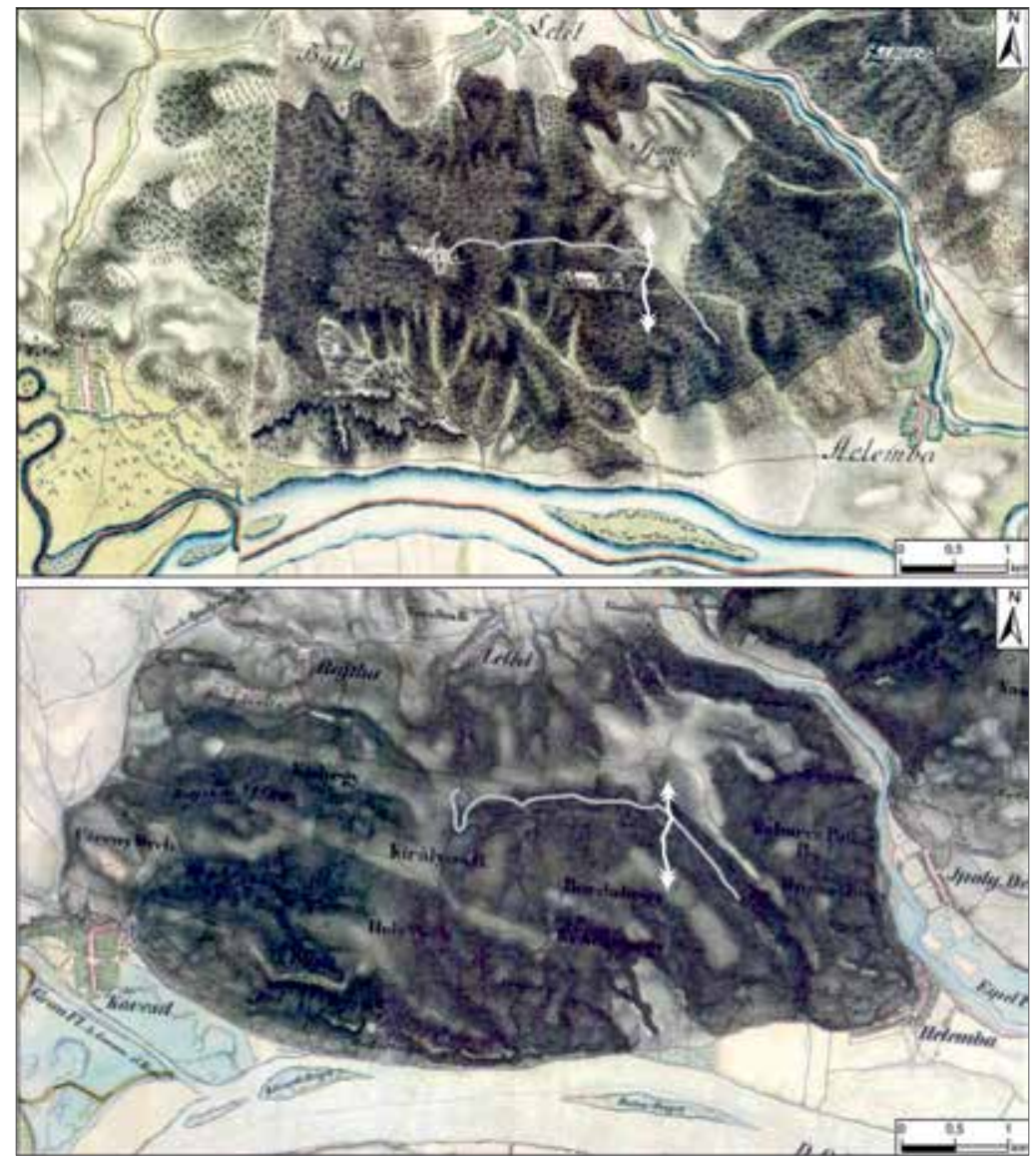

Obr. 5. Pohorie Burda na prvom (hore) a druhom (dole) vojenskom mapovaní. V severovýchodnej časti pohoria viditel’ná výrazná odlesnená enkláva na prvom vojenskom mapovaní s pomenovaním Sjaniec B. (Šancový vrch). Biela línia - situovanie zemného valu, šedá línia - lesná cesta Dona potok. Zdroj https://www.arcanum.hu/hu/mapire/; doplnila N. Beljak Pažinová.

Abb. 5. Burda-Gebirge auf der ersten (oben) und zweiten (unten) militärischen Kartierung. Auf der ersten militärischen Kartierung ist im nordöstlichen Teil des Gebirges eine deutliche abgeholzte Enklave mit der Bezeichnung Sjaniec B. (Schanzenhügel) zu erkennen. Weiße Linie - Lage des Erdwalls, graue Linie - Waldweg Dona potok. Quelle https://www.arcanum.hu/hu/mapire/; ergänzt von N. Beljak Pažinová.

Práca bola podporená Agentúrou na podporu výskumu a vývoja na základe zmluvy č. APVV-0063-17 „Vita intra muros - interdisciplinárny výskum hradov stredného Slovenska“.

\section{Literatúra}

BELJAK PAŽINOVÁ, N.-ŠALIOVÁ, S., 2017: Zabudnutý cintorín Kakathu objavený?, Studia Historica Nitriensia 21 - Supplementum 1, 35-47.

BEDNÁR, P., 2012: Počiatky Nitrianskeho hradu. In: Nitriansky hrad a Katedrálny chrám - Bazilika sv. Emeráma (Judák, V., ed.), 45-46. Nitra.

BEDNÁR, P.-SAMUEL, M., 2004: Entwicklung der Befestigung der Nitraer Burg im 11. Jahrhundert, SlArch XLIX, 328-330.

BELJAK, J., 2010: Spečené valy v Honte. In: Zlatá kniha Hontu (Urban, P. et al., edd.), 359-362. Martin. 
BOROVSZKY, S., 1906: Hont vármegye és Selmeczbánya sz. kir. város. Magyarország Vármegyéi és Városai. Budapest.

HEGYI, K., 2007: A török hódoltság várai és várkatonasága. II. kötet. Budapest.

HENSZLMANN, I., 1878: Úti jegyzetek, Archeológiai Értesítő 12, 247-251.

ISTVÁNOVITS, E.-KULCSÁR, V., 2002: The History and perspectives of the research of the Csörsz Ditch (Limes Sarmatiae). In: Limes XVIII. Proceedings of the 18th international Congress of Roman frontier Studies held in Amman, Jordan (Freeman, P. et al., edd.), 625-627. Budapest.

IVANIČ, P., 2011: Stredoveká cestná siet’ na Pohroní a Poiplí. Nitra.

JANŠÁK, Š., 1938: Staré osídlenie Slovenska. Dolný Ipel' a Hron v praveku. Turčiansky Sv. Martin.

JÁRDÁNYI-PAULOVICS, I., 1949: A vasvári régészeti kutatások eredményei az 1948. évben. Debrecen.

KISS, G.-TÓTH, E., 1987: A vasvári „Római sánc“ és a „Katonák útja“ időrendje és értelmezése. (Adatok a korai magyar gyepürendszer topográfiájához I.) - Die Chronologie und Interpretierung des „Römischen Walles“ und der „Heerstraße“ zu Vasvár (Beiträge zur Topographie des frühungarischen Verhaugürtelsystems I.), Communicationes Archaeologicae Hungariae 1987, 101-137.

- 2001: A vasvári sánc. Határvédelem az Árpád-korban, Élet és Tudomány 56/33, 1035-1037.

KNAUZ, F., 1874: Monumenta ecclesiae Strigoniensis. Tomus primus.

KOLNÍK, T., 1978: Zist'ovací výskum tzv. spečeného valu v Žemberovciach - Feststellungegrabung des sog. verbrannten Walles in Žemberovce. In: AVANS 1977, 139-141. Nitra.

- 1999: Gab es einem Limes Quadurorum? Langwälle in der Südwestslowakei. In: Germanen beiderseits des spätantiken Limes. Spisy archeologického ústavu AV ČR Brno 14 (Tejral, J.-Fischer, Th.-Precht, G., edd.), 163-177. Köln - Brno.

KOLNÍK, T.-ROTH, P., 1984: Zist'ovací výskum tzv. dlhého valu v Novom Tekove - Probegrabung im sog. langen Wall in Nový Tekov. In: AVANS 1983, 120-122. Nitra.

KORCSMÁROS, L., 1995: Ipolydamásd története 1262-1990. Ipolydamásd.

MEDVECKÝ, K., 1924: Andrej Kmet', jeho život a dielo. Bojnice.

MÉSZÁROS, Gy., 1997: Erdőgazdálkodás a honfoglalás után, Erdészeti Lapok 132/6, 192-193.

MIKLÓS, Zs., 1989: Ipolydamásd várai, Váci Könyvek 4, 7-28.

- 1990: Ipolydamásd-Zuvár. In: Castrum Bene 1989. Várak a 13. században (Horváth, L., ed.), 190-195. Gyöngyös.

MORDOVIN, M., 2013: Archeologický výskum komitátneho Hontianskeho hradu, Acta Historica Neosoliensia 16, 6-37.

NOVÁKI, Gy., 1964: Zur Frage der sogenannten Brandwälle in Ungarn, Acta Archaeologica Academiae Scientiarum Hungaricae 16, 99-149.

NOVÁKI, Gy.-SÁNDORFI, Gy., 1987: A soproni belváros „vörös sánca” kutatásának eredményei, Soproni Szemle 41, 38-48.

NOVÁKI, Gy.-SÁNDORFI, Gy.-MIKLÓS, Zs., 1979: A Börzsöny hegység őskori és középkori várai. Budapest.

PIŠÚT, P.-PROCHÁZKA, J.-BANDURA, P., 2016: Pohorie Burda na starších mapách - Burda Mts. on historical maps, Ochrana prírody 27, 5-21.

RÓMER, F., 1876: Román- és átmenetkorú építmények hazánk területén, Archaeológiai Közlemények 10/2, $1-61$.

SOPRONI, S., 1969: Limes Sarmatiae, Archeológiai Értesítő 96, 43-53.

ŠTEFANOVIČOVÁ, T., 1975: Bratislavský hrad v 9.-12. storočí. Bratislava.

- 1987: A szlovákiai égett sáncok kérdéséhez, Soproni Szemle 41, 340-347.

- 1998: Neufunde aus der Bratislavaer Burg. In: Frühmittelalterlicher Burgenbau in Mittel- und Osteuropa (Henning, J.-Ruttkay, A. T., edd.), 427-434. Bonn.

VADAY, A., 2001: Militia inermis, militia armata. Bemerkungen zur Frage des Limes Sarmatiae, SlArch XLIX, 249-276.

VAŠKOVÝCH, I. et al., 1982: Vysvetlivky ku geologickej mape juhovýchodnej časti Podunajskej nížiny $1: 50$ 000. Bratislava.

\section{Zusammenfassung}

\section{Die Wallbefestigung im Burda-Gebirge in der Slowakei}

Das Burda-Gebirge (älterer Name die Kováčov-Hügel; ungarisch Helembai-Hegység) befindet sich im südöstlichen Teil des südwestlichen Gebietes der Slowakei an der Grenze zur Republik Ungarn zwischen der Mündung der Flüsse Eipel und Gran in die Donau (Abb. 1: oben). Obwohl 
der Wall im Burda-Gebirge bereits in Publikationen von der Wende des 19. und 20. Jahrhundert Erwähnung findet, wurde er archäologisch bisher noch nicht untersucht. Im Rahmen der vom Lehrstuhl für Archäologie der Philosophischen Fakultät der Universität Konstantin der Philosoph Nitra im Jahr 2013 bei einer Verbreiterung des von der Gemeinde Bajtava nach Chlaba durch das Burda-Gebirge führenden Waldweges Dona potok durchgeführten archäologischen Rettungsgrabung ist es gelungen, diese Erdwallbefestigung zu lokalisieren und den gegebenen Möglichkeiten nach entsprechend zu dokumentieren.

Der Wall, der den ursprünglichen Weg bereits in der Vergangenheit gekreuzt hat, wurde an der Stelle im Profil dokumentiert, wo er den Waldweg Dona potok kreuzte (Abb. 2). Das erhaltene Südprofil des Walles wurde über die gesamte Breite von Hand gesäubert (Abb. 3). Die Länge des Walles erreichte an der Grundlinie $13 \mathrm{~m}$, und die maximale Höhe in der Mitte des Profils betrug fast $3 \mathrm{~m}$ mit einem allmählichen auf beiden Seiten mehr oder weniger gleichmäßigen Gefälle (Abb. 4). Der Wallboden besteht aus einer hellgelben lössartigen Lehmschicht, auf der ein gröberer Streifen Steine aus lokalen vulkanischen Vorkommen lag (Andesiten, Brekzien). Diese haben sich in Richtung Wallränder verloren. Der Wallverlauf konnte im Gelände über eine Gesamtlänge von ca. $1 \mathrm{~km}$ gemessen werden (Abb. 1). Im Burda-Gebirge ist der Wall in Nord-Süd-Richtung orientiert und verläuft von dem Teil des Burdovhügels, wo der höchste Punkt des Walles eine Höhe von fast $300 \mathrm{~m}$ über dem Meeresspiegel erreicht und durch den nördlichen Teil des Gebirges fließend abfällt, wo er eine Höhe von $250 \mathrm{~m}$ über dem Meeresspiegel erreicht.

An der Schnittstelle durch den Wall im Burda-Gebirge wurden keine Überreste einer Holzpalisade, bzw. keine verbrannte Erde oder eventuelle Holzkohlereste gefunden, die für vergleichbare Erdbefestigungslinien charakteristisch sind. Es wurden dort auch keine archäologischen Funde entdeckt, die eine nähere Einordnung des Objektes ermöglichten. In der gegenwärtigen Situation ist es also nicht möglich, die Zeit des Wallbaus bzw. seine Funktion oder seinen Zweck zu betimmen. Jedoch besteht kein Zweifel daran, dass es sich dabei um ein anthropogenes Relikt handelt und aufgrund seiner Lage die Barrikade eines Weges (von Wegen?) bildete, die von Osten her (Eipeltal) quer durch das Burda-Gebirge nach Westen (Grantal) verlief.

Obwohl ein durch das Burda-Gebirge verlaufender Erdwall in den analysierten Quellen nicht eindeutig erwähnt wird, ist es klar, dass bei seiner Errichtung bewegte Kriegszeiten den Schlüssel bilden, die wir vorerst jedoch nicht genau einordnen können. Auch eine wiederholte Nutzung des Objektes in verschiedenen Zeiten kann nicht ausgeschlossen werden. Ein interessantes Indiz für die Existenz einer Befestigung im Burda-Gebirge liefert die historische militärische Kartierung aus dem 18. Jahrhundert (Abb. 5), in der sich im nordöstlichen Teil des Gebirges in der Nähe der Fundstelle des Walles wiederholt eine abgeholzte Enklave und die Bezeichnung „Schanze“ auftaucht.

Die vorliegende Arbeit wurde von der Agentur zur Förderung von Forschung und Entwicklung durch Vertrag Nr. APVV-0063-17 „Vita intra muros - interdisziplinäre Erforschung von Burgen der Mittelslowakei“ gefördert.

doc. PhDr. Noémi Beljak Pažinová, PhD., Katedra archeológie Univerzity Konštantína Filozofa v Nitre, Hodžova 1, 94974 Nitra, Slovenská republika,nbpazinova@ukf.sk 
